\title{
Seeing the oakscape beyond the forest: a landscape approach to the oak regeneration in Europe
}

\author{
Andrzej Bobiec $\mathbb{D} \cdot$ Albert Reif $\mathbb{D} \cdot$ Kinga Öllerer $\mathbb{C}$
}

Received: 28 July 2017 / Accepted: 7 February 2018/Published online: 19 February 2018

(C) The Author(s) 2018. This article is an open access publication

\begin{abstract}
Context Intensification and specialisation of agriculture and forest use has led to profound structural and compositional changes in European landscapes. In particular, sharp, narrow edges adjacent to relatively homogenous vegetation types progressively replace transitional habitats, crucial for a plethora of species and ecological processes. Quercus robur and $Q$. petraea regeneration niches make them best adapted to such transitional habitats. However, contemporary
\end{abstract}

Electronic supplementary material The online version of this article (https://doi.org/10.1007/s10980-018-0619-y) contains supplementary material, which is available to authorized users.

\section{A. Bobiec $(\square)$}

Faculty of Biology and Agriculture, University of Rzeszów, ul. Ćwiklińskiej 1a, 35-601 Rzeszów, Poland e-mail: a_bobiec@ur.edu.pl

\section{A. Reif}

Chair of Site Classification and Vegetation Science, University of Freiburg, Tennenbacherstr. 4, 79085 Freiburg, Germany

e-mail: albert.reif@waldbau.uni-freiburg.de

\section{K. Öllerer}

Institute of Biology Bucharest, Romanian Academy, Spl. Independenţei 296, 060031 Bucharest, Romania

e-mail: kinga.ollerer@gmail.com

K. Öllerer

MTA Centre for Ecological Research, Institute of Ecology and Botany, Alkotmány u. 2-4, 2163 Vácrátót, Hungary oaks' importance, including their regeneration, is usually considered within limits of forest habitats.

Objective Defining habitats, landscape patterns and processes fostering oak regeneration and 'oakscape' development.

Methods We assessed the state-of-the art of the topical literature with respect to various aspects of oak regeneration based on a refined list of 234 titles from the Web of Science database.

Results The review confirmed that the vast majority of studies focus on forest habitats, disregarding the fact that substantial part of acorns are being carried away and seeded by birds in non-forest habitats.

Conclusions The common acceptance of the simplistic landscape mosaic model, based on segregated homogenous vegetation categories and clear-cut lines separating patches, impedes proper assessment of landscape changes, referring to 'untypical', transitional habitats- the true oaks' domain. Hence, restoring and sustaining European 'oakscape' should result from the overall landscape management, based on a better adapted gradient approach to landscape studies. Applying such an approach, we identified a set of habitats fostering successful oak regeneration and recruitment without direct human support, contributing to the contemporary 'oakscape', represented mostly by non-forest, either natural or anthropogenic habitats. 
Keywords Acorn dispersal - Colonisation strategy · Cultural landscapes · Forest bias · Landscape approach · Oakscape · Quercus · Regeneration failure · Synanthropic opportunism

\section{Introduction}

The anthropogenic factor has been an important driver shaping the landscapes since pre-historic times. The multiple use of land sustained the complex and dynamic spatial fabric of the wooded component in a dynamically open matrix, allowing migration of species and gene flow throughout landscapes and larger spatial units (Vera 2000; Bruun and Fritzbøger 2002). One of the major features of historical landscapes were open woodlands and savannah-type communities sustained by intricate systems of woodmanship and silvopastoralism (Vera 2000; Rackham 2006; Samojlik et al. 2016). Unlike modern forests delineated by a sharp edge line, silvopastoral woods have a wide interface with treeless communities, permeable to migrating species contributing to conspicuously high biodiversity (Garbarino and Bergmeier 2014; Plieninger et al. 2015).

The spread of modern forestry, which concentrated on timber growth, coincided with the introduction of highly productive agricultural crops (including plants used for fodder). This increased the material productivity, but also resulted in deepening spatial segregation and increasing specialisation of both land uses. Enforced by legal solutions (e.g., bans on fire use and livestock grazing in woodlands), modern land management has led to disappearance of the traditional multiple-purpose semi-open wooded landscapes and their associated communities (Vera 2000; Rackham 2006). This recent development had a dramatic effect on a plethora of species, which used to flourish in the formerly wide interface zones (Garbarino and Bergmeier 2014). Among the woody plants, that for millennia have benefitted from semi-natural, extensively used habitats, are oaks, Quercus spp.

Although the change in the use of land was triggered by the agricultural and industrial revolutions in late 1600 s to early 1700 s, its visual and ecological effects became apparent only in the last century (e.g., Rackham 2006; Samojlik et al. 2016), which coincides with the dawn of ecological studies, including the interest for oak regeneration. Perhaps the most quoted topical publication from this period is A.S. Watt's 'On the causes of failure of natural regeneration in British oakwoods' referring to the regeneration of Quercus robur and Q. petraea (Watt 1919). Ever since, he has been followed by dozens of researchers confirming his pessimistic findings from various European regions (e.g. Shaw 1968a, b, 1974; Palmer et al. 2004; Götmark et al. 2005; Perrin et al. 2006; Rackham 2006; Petritan et al. 2013).

The common denominator of those studies is the general characteristic of the research areas: contemporary forest habitats. This corresponds with a segregated approach to landscapes as mosaics of patches representing distinct, relatively homogenous vegetation cover categories. We suspect that such a discrete model of landscape somehow 'determines' the pursuit of oak regeneration confined to woodland patches, in particular where oaks are present in the canopy layer. Deciduous Quercus species are representative components of the canopy in many managed and protected forest types in Europe, and many silvicultural methods were developed to regenerate oak in high forest systems (von Lüpke 1998; Palmer et al. 2004; Annighöfer et al. 2015). However, natural regeneration and successful recruitment into the canopy layer of such forests are usually missing without human support (Vera 2000 and references therein; Bobiec et al. 2011a). We suggest that oak's inherent characteristics, involving zoochoric far-distance 'directed dispersal' of acorns (Montoya et al. 2010 and references therein), imply that regeneration success should not be sought under canopies of most of deciduous (including oak) trees. Oak's performance in historical landscapes and in contemporary non-forest habitats does not support the segregated land-use approach based on clear-cut alternative of closed forest vesus open habitats. New oak groves/stands most commonly emerge either on abandoned grasslands and fallows, or in heavily disturbed/modified forest habitats (e.g., Bobiec et al. 2011b; Minotta and Degioanni 2011; Kowarik et al. 2013), neither of them fitting the sharp 'closed versus open' alternative.

In our view, $Q$. robur and $Q$. petraea are not typical components of the canopy layer of natural forests on mesic to eutrophic sites, as portrayed by archetypal old-growths (e.g., Faliński 1986; Peterken 1996). Instead, as specialised long-lived opportunists, they readily colonize forest areas where unusual, often 
anthropogenic, disturbances have eliminated or substantially alleviated competition of shade-casting trees and tall shrubs. Due to their long life span, oaks may maintain a substantial share in the canopy both in managed and preserved forests, but this does not mean that they represent the 'potential natural vegetation'. The same adaptations that make oaks successful contemporary opportunistic colonisers (in particular far distance zoochoric dispersal of heavy nutrient-rich seeds giving seedlings a competitive advantage during the first year of growth) might had secured their advantage in the post-glacial colonisation of Europe over the late-successional species, including hornbeam (Carpinus betulus) and beech (Fagus sylvatica) (Hewitt 1999; Feurdean et al. 2013).

Although we focus on these two oak species, with their range extending throughout the Atlantic and Continental biogeographic regions of Europe, we also refer to autecological studies of other deciduous oaks from Europe and temperate North America and highlight some analogies between temperate and Mediterranean open woodlands and African savannas.

The main objective of our study was to review the knowledge of the oak regeneration niche, with a particular focus on its adaptations to various habitat characteristics, including site factors and competition, concentrating on the two congeneric oak species. We hypothesise that most of the discussion on the oak regeneration failure is biased by a wrong assumption that oaks belong to the forest domain. From this, we argue that by focusing on forest habitats, the true landscape context of the oak regeneration is ignored.

\section{Materials and methods}

We analysed the papers available in the Web of Science (WoS) database, dealing with the relevant factors of Quercus robur or Q. petraea regeneration. 485 publications were listed using the query formula TOPIC: ('Quercus robur' AND 'regeneration') $O R$ TOPIC: ('Quercus robur' AND 'landscape') $O R$ TOPIC: ('Quercus petraea' AND 'regeneration') $O R$ TOPIC: ('Quercus petraea' AND 'landscape'), with the earliest publication from 1968 and the latest from 2017 (the query was last repeated on June 30, 2017). All hits were exported for title screening, which showed that many proved irrelevant for our study. Eventually, the actual size of the literature sample subject to our analysis was reduced to 234 papers (see Appendix S1 in Supporting Information).

We have identified 16 research issues (phenomena, processes, factors) considered at least by 9 out of the analysed collection of papers in the context of oak regeneration:

Type of studied environment-forest (1), nonforest (2), site conditions (nutrients and water) (3), light availability (or level of photosynthetically active radiation) (4), seed dispersal (5), spatial pattern of regeneration (6), regeneration density (7), saplings growth and survival (8), re-sprouting (9), recruitment duration (10), seedlings/saplings age (11), biomass allocation (12), animal-induced damages (13), growth/ recruitment facilitation (14), competition (from vegetation) (15), and effect of grass vegetation (16). These issues were considered as binary variables (i.e., present or absent in a given paper). Their mutual affinities have been assessed with hierarchal cluster analysis, the Manhattan distance and Ward's fusion method. The differences of associations of the studied issues with forest versus non-forest environments were tested with Chi square goodness of fit test. For statistical analyses we used the Statistica 13.1 (StatSoft) package.

We divided our findings into two major sections: I-oaks' responses to factors affecting their early life stages and II-synthesis of landscape features fostering oak regeneration and recruitment.

\section{Results and discussion}

The collected information provided a concise definition of the oak regeneration niche as realized in European landscapes. All components of the processes and developmental options responsible for presence or absence of successful recruitment, establishment and sustenance of oaks constitute a general model of the 'oakscape', i.e., a landscape fostering oak regeneration, recruitment and long-lasting presence (Fig. 1).

Oaks' responses to factors affecting their regeneration

The cluster analysis of the issues (variables) considered by the reviewed papers revealed two conspicuous groups: one represented by non-forest, variegated habitats (NON-FOREST) and one by forest habitats 
(FOREST). Whilst the problems of seed dispersal and spatial pattern are most commonly investigated in the NON-FOREST context, abiotic environmental conditions (water and nutrients supply), competition and growth/survival have been usually studied in FOREST habitats (Fig. 2).

Because the establishment of a stand is a consequence of seedlings and saplings growth and recruitment, which in turn depend on deposited seeds, one cannot reliably appraise the final tree regeneration effect without considering the entire trajectory, including its very beginning, i.e., the pattern of seed dispersal. However, only 29 out of the 234 analysed papers $(12 \%)$ considered that stage. Not surprisingly, there was significantly higher percentage $(38 \%)$ of studies carried out in the environment of non-forest, variegated habitats described in that sub-sample of papers than in the remaining 174 papers (11\%) (Table 1). This implies that the vast majority of oak regeneration studies refer to specific circumstances of selected habitats but not to the actual range of the trees reproductive effort.

Fig. 1 Synthetic graph showing the major habitat types and processes involving oak regeneration according to the 'oakscape' model

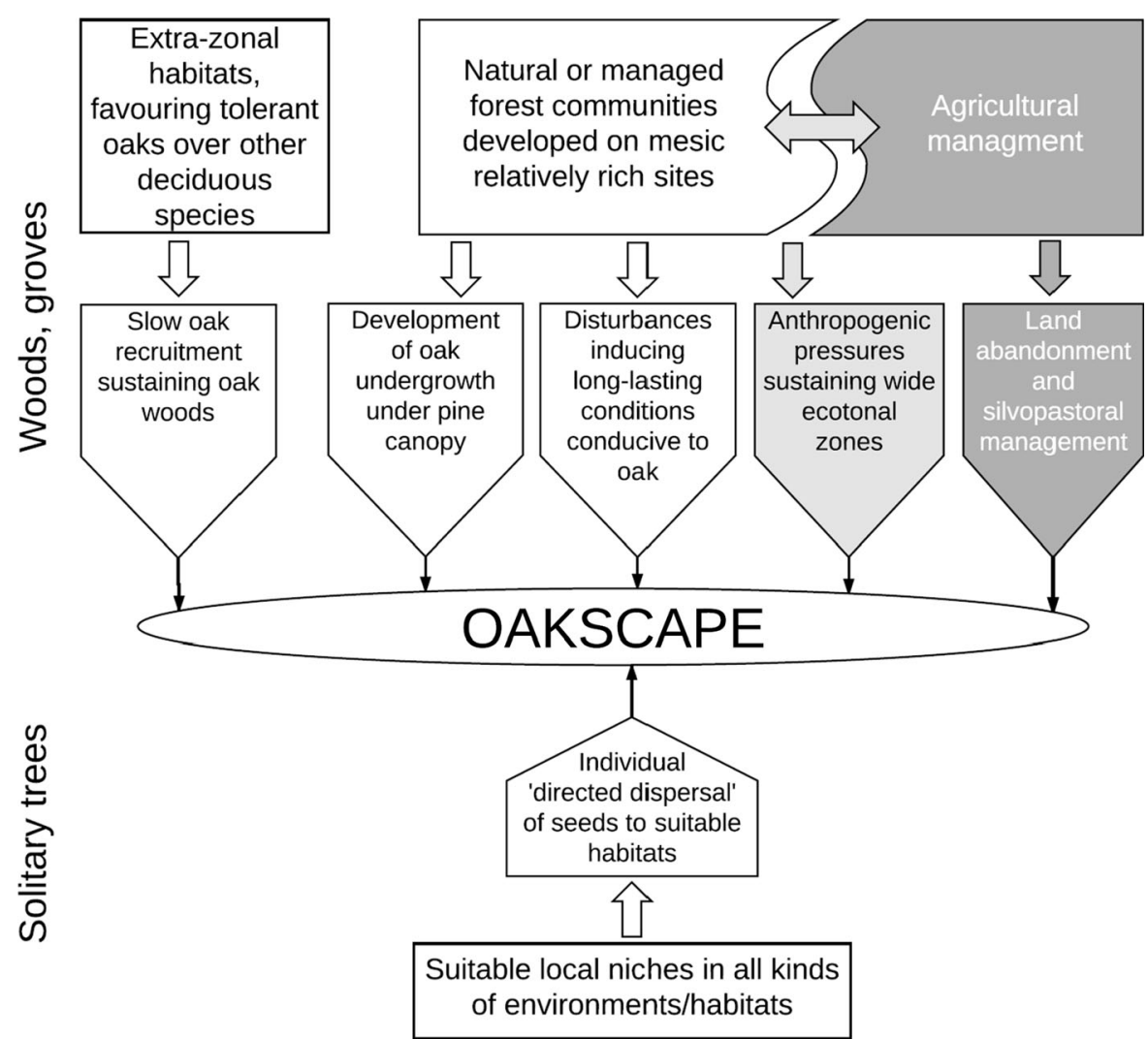

\section{Seed dispersal}

Interestingly, in Watt's study, the zoochoric dispersal was completely ignored and the net role of animals was considered merely as seed predation (Watt 1919). Nowadays, however, there is a well-established awareness of an importance of a mutualistic system of oaks (various species) and Jays, both Eurasian Jay Garrulus glandarius and N. American Blue Jay Cyanocitta cristata (Vander Wall 2001).

Jays, due to their hoarding strategy, are critical oak dispersers throughout landscapes. With the constant potential range of the acorn dispersal, i.e., up to $4 \mathrm{~km}$ (Kollmann and Schill 1996; Vander Wall 2001; Olrik et al. 2012), the realized distance from parent trees to caching sites depends on the individual landscape characteristics (Gómez 2003). Jays prefer non-forest habitats to closed tree canopy for caching, particularly if there are vertical structures that can be used as navigation beacons (Kollmann and Schill 1996; Herlin and Fry 2000), and diversified with forest patches (Morán-López et al. 2015). There is a strong correspondence between the Jay habitat selectivity and the 


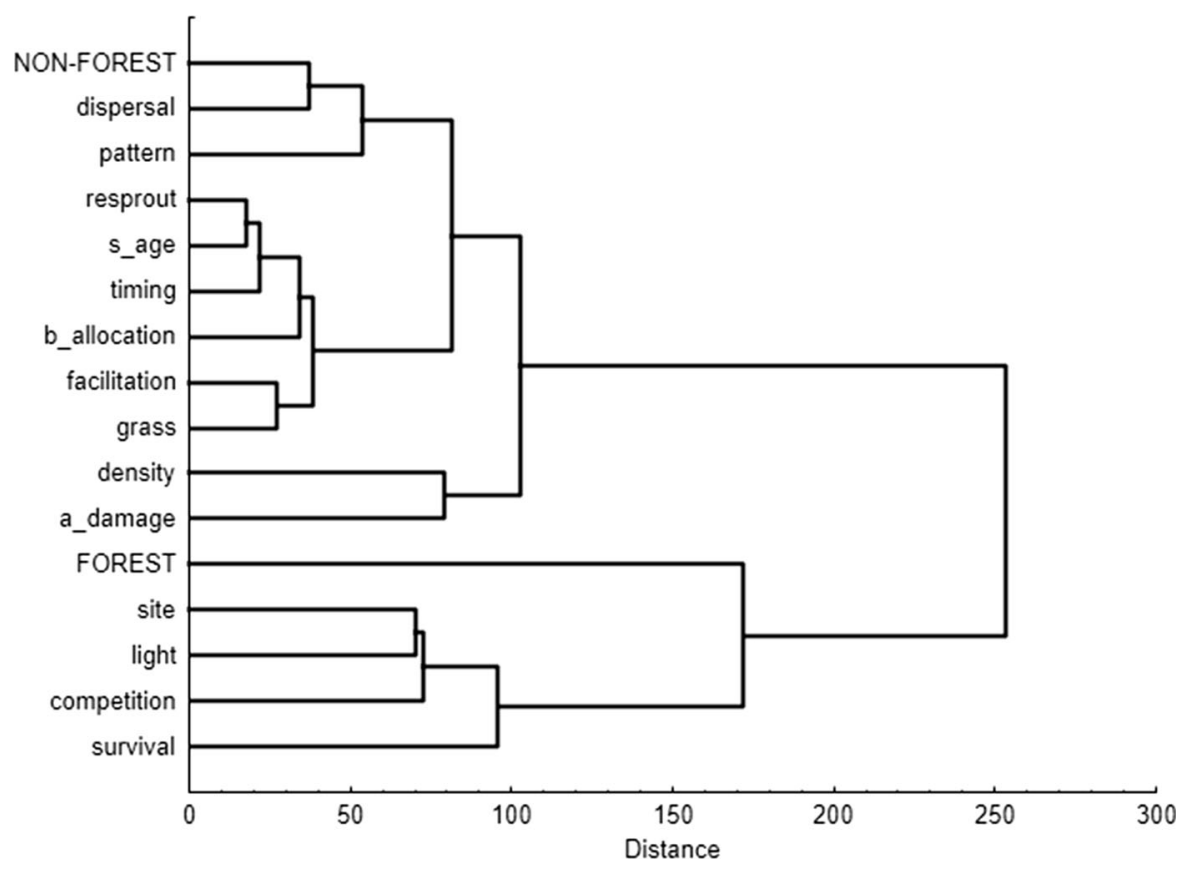

Fig. 2 Clusters of 16 binary variables representing issues related to oak regeneration, occurring in the collection of the 234 reviewed papers. FOREST-environment; NON-FORESTnon-forest or variegated landscape; dispersal-seed dispersal; pattern-spatial pattern of oak regeneration; resprout-resprouting oak saplings; s_age-seedlings/saplings age;

environmental needs and preferences of oaks (Myczko et al. 2014, Table 2). Barochoric seed fall is usually less likely to establish viable regeneration, than are acorns selected and transported by birds, which firmly hammer them into the soil, securing a better protection against predation and desiccation (Kollmann and Schill 1996; Vander Wall 2001).

Another complementary, positive agent of oak regeneration in heterogeneous landscapes are rodents. At the local scale, rodents proved to be not only seed predators but also efficient dispersers of viable acorns. Due to the series of partial consumption followed by re-caching, the effective dispersal distance can reach $132 \mathrm{~m}$ (Perea et al. 2011c). According to Perea et al. (2011a, c) most of the re-dispersed acorns, even those partly eaten by rodents, retain the potential for germination and development of well-shaped seedlings. Rodent dispersal effect depends on specific structural habitat characteristics, including scrub or piled branches offering shelter, and open sites covered by unmown tall herbaceous vegetation (Kollmann and Schill 1996; den Ouden et al. 2005; Perea et al. 2011c). timing—recruitment duration; b_allocation-(young oaks) biomass allocation; facilitation-growth/recruitment facilitation; grass - effect of grass vegetation; density-regeneration density; a_damage — animal-induced damages; site-site conditions; light-light availability; competition-competition from vegetation; survival—saplings growth and survival

In the case of holm oak Quercus ilex woodlands in the Iberian Peninsula, Morán-López et al. (2015) revealed that increasing forest fragmentation and insufficient shrub cover (under 65\%) outside forest have changed the rodents' influence on oak regeneration. Their positive net effect (seed dispersal and caching) became overwhelmed by the negative effect (seed consumption). The study by Muñoz and Bonal (2007), carried out in similar habitats, indicates that the presence of ungulates (deer and wild boars) might substantially change the rodents' hoarding strategy, affecting the oak's regeneration success.

\section{Germination and early seedling growth}

Although the seed dispersal mechanism determines the potential range of a species, its actual occurrence depends on germination, growth and recruitment conditions in the place where it has been deposited. The major fraction of acorns falling on the ground fail to produce viable seedlings due to unfavourable abiotic conditions (drought in particular) and hostile 
Table 1 Connection of selected topics with two categories of studied habitats in the collection of $234^{\mathrm{a}}$ papers selected from the Web of Science database; integrals-number of occurrences; numbers in parentheses-percent share

\begin{tabular}{|c|c|c|c|c|}
\hline & & NON-FOREST & FOREST & Two-tailed P \\
\hline & $\mathrm{N}$ & $29(100)$ & $174(100)$ & $0.000 *$ \\
\hline \multirow[t]{2}{*}{ Oak species } & Q. robur & $27(93)$ & $142(82)$ & 0.450 \\
\hline & Q. petraea & $7(24)$ & $71(41)$ & $0.047 *$ \\
\hline \multirow[t]{14}{*}{ Identified research issues } & Saplings growth and survival & $11(38)$ & $78(45)$ & 0.510 \\
\hline & Regeneration density & $10(34)$ & $54(31)$ & 0.804 \\
\hline & Light availability & $4(14)$ & $56(32)$ & $0.012 *$ \\
\hline & Animal-induced damage & $9(31)$ & $45(25)$ & 0.504 \\
\hline & Site conditions & $7(24)$ & $46(26)$ & 0.888 \\
\hline & Competition from vegetation & $6(21)$ & $46(26)$ & 0.560 \\
\hline & Spatial pattern of regeneration & $11(38)$ & $40(23)$ & 0.073 \\
\hline & Seed dispersal & $11(38)$ & $19(11)$ & $0.000 *$ \\
\hline & Grass effect & $4(14)$ & $14(8)$ & 0.286 \\
\hline & Growth/recruitment facilitation & $6(21)$ & $11(6)$ & $0.007 *$ \\
\hline & Recruitment duration & $3(10)$ & $12(7)$ & 0.628 \\
\hline & Biomass allocation & $1(3)$ & $13(7)$ & 0.343 \\
\hline & Seedlings/saplings age & $1(3)$ & $9(5)$ & 0.221 \\
\hline & Re-sprouting & $0(0)$ & $8(5)$ & 0.074 \\
\hline
\end{tabular}

${ }^{\text {a }}$ Thirty-one papers not considered in the table deal with various aspects of oak regeneration studied in controlled artificial conditions *Significant deviation of percent shares ratio from 1:1, Chi square goodness-of-fit, Yates correction

biotic factors, such as pathogenic fungi (especially Phytophthora spp.-Jonsson et al. 2003), insect infestation (weevil Curculio glandium-Crawley and Long 1995) and predation (rodents-Watt 1919). Whereas, according to Pausas et al. (2009), <20\% of fallen acorns are viable, Perea et al. (2011b) have shown Jays removing acorns from trees preferred sound seeds over insect-infested seeds. Therefore, acorns collected by birds from trees and planted outside the oak canopy have higher chance for successful germination, and the emerging seedlings are exposed to lower risk of lethal infection or destruction. If the seedbed is located in an open habitat, the seedlings survival and growth success will be radically amplified by favourable light conditions (Watt 1919; Bakker et al. 2004; Van Uytvanck et al. 2008; Jensen et al. 2012).

The character of seedbed, including the type of vegetation cover, is a chief determinant of the success or failure of germination. According to A.S. Watt, "a grassy surface seems the natural seedbed of oak, for very successful examples may often be seen on rough pasture adjoining woods which for some reason or other has been allowed to lie waste or is only slightly stocked with cattle during the summer" (Watt 1919, p. 175). Numerous later studies support that observation, revealing successful oak regeneration in grassdominated vegetation with scattered trees or shrubs (e.g., Kollmann and Schill 1996; Kuiters and Slim 2003; Minotta and Degioanni 2011; Perea et al. 2011a), particularly in the neighbourhood of forest/woodland edges or hedgerows (e.g., Herlin and Fry 2000; Olrik et al. 2012; Morán-López et al. 2015). As suggested by Bobiec et al. (2011b) this may be due to the grassy sod preventing the access to soil seedbed by light wind-born seeds and therefore retarding succession and favouring slow and gradual regeneration of trees and shrubs from heavier seeds brought by animals, including oaks and fruit woody species.

Although we have not found any study of a systematic comparison of the effect of grass versus other types of vegetation on oak regeneration, there are two important premises, which might substantiate the grass advantage over forb communities. Forbs cast more shade comparing to grass (e.g., bracken- 
Table 2 A synthetic collection of oak's adaptations to major factors affecting its regeneration

\begin{tabular}{|c|c|c|c|}
\hline Stage & Specific disadvantages/negative factors & $\begin{array}{l}\text { Compensation/defense } \\
\text { mechanisms }\end{array}$ & Regeneration strategies \\
\hline \multirow{4}{*}{$\begin{array}{l}\text { Seed supply: } \\
\text { relatively } \\
\text { irregular } \\
\text { masting }\end{array}$} & $\begin{array}{l}\text { Competition from fast-growing tree } \\
\text { species, with annual abundant seed rain }\end{array}$ & $\begin{array}{l}\text { Long-distance } \\
\text { zoochory }\end{array}$ & $\begin{array}{l}\text { Escape to sites unaffected by pioneers' } \\
\text { invasion (e.g., covered with dense } \\
\text { graminoid sod) }\end{array}$ \\
\hline & $\begin{array}{l}\text { Competition from stress-tolerant species, } \\
\text { with abundant 'stand-by' seedling and } \\
\text { sapling bank (shade-tolerant species) }\end{array}$ & $\begin{array}{l}\text { Long-distance } \\
\text { zoochory }\end{array}$ & $\begin{array}{l}\text { Escape to sites free from shade-tolerant } \\
\text { species: dry sites with long vegetation } \\
\text { period; alluvial sites; graminoid sod } \\
\text { preventing undergrowth development; fire } \\
\text { succession }\end{array}$ \\
\hline & \multirow[t]{2}{*}{ Predation } & $\begin{array}{l}\text { Long-distance } \\
\text { zoochory }\end{array}$ & $\begin{array}{l}\text { Escape to sites with lower population sizes of } \\
\text { acorn-dependent forest rodents }\end{array}$ \\
\hline & & Predator satiation & $\begin{array}{l}\text { More efficient dispersal and caching by } \\
\text { satiated forest rodents }\end{array}$ \\
\hline \multirow[t]{4}{*}{$\begin{array}{l}\text { Germination } \\
\text { to seedling } \\
\text { development }\end{array}$} & Infections/infestations/putrefaction & $\begin{array}{l}\text { Long-distance } \\
\text { zoochory }\end{array}$ & $\begin{array}{l}\text { Avoiding high-risk areas (particularly in the } \\
\text { shade of oak canopy, with hypothetically } \\
\text { highest content of oak-specific pathogenic } \\
\text { agents) }\end{array}$ \\
\hline & \multirow[t]{2}{*}{ Desiccation } & $\begin{array}{l}\text { Long-distance } \\
\text { zoochory deep } \\
\text { rooting system }\end{array}$ & \multirow[t]{2}{*}{$\begin{array}{l}\text { Caches under shallow ground, grass sod or } \\
\text { moss cover securing optimal moisture } \\
\text { conditions }\end{array}$} \\
\hline & & $\begin{array}{l}\text { Ability to regulate } \\
\text { transpiration by } \\
\text { stomata closure }\end{array}$ & \\
\hline & $\begin{array}{l}\text { Competition of herb layer vegetation (for } \\
\text { light, macro-elements) }\end{array}$ & $\begin{array}{l}\text { Initial independence } \\
\text { from external energy } \\
\text { and nutrient } \\
\text { resources }\end{array}$ & $\begin{array}{l}\text { Starch-rich acorns allow germinants develop } \\
\text { into one-year-old saplings almost without } \\
\text { light and mineral resources }\end{array}$ \\
\hline \multirow[t]{4}{*}{$\begin{array}{l}\text { Sapling } \\
\text { growth/ } \\
\text { recruitment }\end{array}$} & $\begin{array}{l}\text { Stress: lack of light (photosynthetically } \\
\text { active radiation, PAR) }\end{array}$ & $\begin{array}{l}\text { Long-distance } \\
\text { zoochory }\end{array}$ & $\begin{array}{l}\text { Escape to more open or moist sites (moisture } \\
\text { to some extent compensates shade- } \\
\text { intolerance) }\end{array}$ \\
\hline & \multirow[t]{3}{*}{ Browsing/grazing } & $\begin{array}{l}\text { Biomass allocation to } \\
\text { root system, healing, } \\
\text { regrowth } \\
\text { Resprouting potential }\end{array}$ & \multirow[t]{3}{*}{$\begin{array}{l}\text { With higher PAR level (open/semi-open sites) } \\
\text { faster photosynthesis, more efficient } \\
\text { compensation of injuries, higher survival } \\
\text { rate }\end{array}$} \\
\hline & & $\begin{array}{l}\text { Associational } \\
\text { resistance }\end{array}$ & \\
\hline & & Numeric dilution & \\
\hline
\end{tabular}

Humphrey and Swaine 1997), and presumably, following Bossema (1979), may be less favoured by hoarding Jays_-seedlings would be more difficult if not impossible to refind when under the canopy of broad forb leaves. However, fallow fields colonized mostly by birch, which is more permeable to solar radiation than other broad-leaved species, may still be suitable habitats, given oaks shade intolerance (Bobiec et al. 2011b).

\section{Advanced growth and recruitment}

Due to the relatively slow growth in height, oak seedlings are particularly susceptible to competition from the surrounding vegetation. A recent experimental study by Jensen and Löf (2017) proved less competitive impact of herbaceous vegetation on $Q$. robur saplings compared to the impact of woody vegetation. In the absence of trees or shrubs, with sunlight levels acceptable for the satisfactory growth 
of oak (von Lüpke 1998), grasslands and other open or semi-open habitats are favourable habitats for the emergence of young oaks (Kollmann and Schill 1996; Herlin and Fry 2000; Bakker et al. 2004; Van Uytvanck et al. 2008). For instance, in the postagricultural outskirts of the Białowieża National Park, overgrown by the dense vegetation dominated by tall grasses and forbs $(50-100 \mathrm{~cm})$ numerous tall oak (Q. robur) saplings suggest the future development of oak-dominated groves (Bobiec et al. 2011b). Similarly, in sub-Carpathian SE Poland as well as in Ukrainian Prykarpattia Prykarpattya, successful oak regeneration occurs in grasslands dominated by tall grasses (Ziobro et al. 2016). For the same reason, large long-lasting forest gaps, such as those created by the sudden breakdown of spruce-dominated stands, where the presence of shade-tolerant advance regeneration is scarce, commonly invite oak colonization (Bobiec et al. 2011a; van Ginkel et al. 2013).

The fact that oaks regenerate and grow freely in almost all open areas but not within woods might be an adaptation response to the introduction of oak mildew at the beginning of the 20th c. in Europe. The fungus "has little effect on oaks growing in the open (...) it seems to make oak a more light-demanding tree" (Rackham 2006, p. 68). In fact, with reduced photosynthesizing efficiency of the fungus-impaired leaves, young oaks might have lost their former capacity of survival and growth under forest conditions, but remained strong competitors in well-lit non-forest sites. However, based on a comprehensive review of the literature on Erysiphe alphitoides on oak seedlings and saplings, Marçais and Desprez-Loustau (2014) pointed to a high variability among young oak specimens with regard to their susceptibility to mildew. They suggested a selective role of the fungus, leading to a higher mildew resistance in future oak populations.

The only continuous tree canopy cover that allows oaks to regenerate is that of open-worked crown architecture, translucent to the minimum photosynthetically active radiation (PAR) necessary for oak saplings growth and recruitment. Such conditions are met by pine stands, widely propagated by forestry, often on potential sites of mixed or deciduous forests, in most European biogeographical regions (e.g., Kuiters and Slim 2003; Onaindia et al. 2013). Underneath the canopy permeable for at least $30 \%$ of full sunlight (von Lüpke 1998), they foster development of the profuse oak undergrowth unhampered either by major disturbances (compared to mowing or heavy grazing), or by shade-tolerant competitors, such as beech (Fagus sylvatica) or hornbeam (Carpinus betulus).

The described habitats may reflect the natural process of Europe's colonisation of by oak between the Pre-boreal and Atlantic periods, when the widespread pine forests became subjected to the invasion of broad-leaved species with oaks among the fastest progressing colonisers (Feurdean et al. 2013).

\section{The impact of vertebrate herbivory}

Although invertebrates and small vertebrates can locally contribute to a high level of mortality among the assemblages of juvenile oaks (Watt 1919; Kuiters and Slim 2003; Bakker et al. 2004), the impact of grazing/browsing by ungulates remains one of the most discussed ecological issues. Most forest ecologists and practitioners are convinced that both livestock and wild ungulates are among the biggest threats to oak regeneration in forests (e.g., Palmer et al. 2004; Götmark et al. 2005). However, the recently performed experimental roe deer browsing of the young sessile oak open plantation in $\mathrm{S}$ France revealed delayed growth, but no significant seedling mortality increase compared to protected seedlings (Bideau et al. 2016). According to F. Vera, sustaining the open character of landscapes through grazing is indispensable for successful oak regeneration (Vera 2000; Vera et al. 2006). Under such conditions however, oak saplings require a strong anti-grazing/browsing protection, through either facilitation secured by unpalatable species (such as thorny shrubs, e.g., Watt 1919; Kuiters and Slim 2003; Smit and Ruifrok 2011; Jensen et al. 2012), or numeric dilution-an effect of the exuberance of plants more palatable than young oaks (Jensen et al. 2012).

\section{Fire, a neglected factor}

The fact that most of the forest fires that occur in temperate Europe are confined to pine forests (Adámek et al. 2016, Feurdean et al. 2017) should not avert our interest in the role of this factor in oak regeneration. The development of human communities and economies in the Holocene coincided with the oaks' post-glacial re-conquest of land, so man-set fires 
were among the factors shaping landscapes colonized by Quercus species (Jamrichová et al. 2017). However, the pervasive and consequent policy of fire prevention during the last two centuries has dramatically changed its public perception from a tool of management to highly dangerous manifestation of criminal acts. Unlike in Europe, where except for boreal and Mediterranean regions, fire has not been recognized as an important factor of ecosystems dynamics, numerous American studies show that in richer and more humid sites fire is the most important disturbance factor of the oak competitive advantage over shade-tolerant competitors or fast growing pioneering species (e.g., Frelich and Reich 2002; Johnson et al. 2009). Hanberry et al. (2014) have proven oak establishment decline in Missouri Plains between 1815 and 2008 correlated with the loss of the savannah vegetation, transformed into dense forest. The major culprit was abandonment of grass burning.

In our collection, only one paper dealt with fire as influencing oak regeneration. According to Proença et al. (2010), Q. robur is an efficient post-fire resprouter. Other authors implied the historic role of fire on oak regeneration indirectly, on the basis of dendroecological reconstruction studies (e.g., Bobiec 2012). In their recent study, Adámek et al. (2016) compared the fire resistance of several European tree species $(\mathrm{DBH}>20 \mathrm{~cm})$, proving sessile oak even more tolerant than Scotch pine.

In West Ukrainian Prykarpattya, grassland fires, though illegal, penetrate into the border zones of woods, efficiently preventing hazel (Corylus avellana) regrowth as well as the development of dense undergrowth of hornbeam and beech. This favours scattered, but continuous regeneration of $Q$. robur, developing open, savannah-like stands (Ziobro et al. 2016). Despite these positive effects, we call for caution in the use of fire, especially when this is done as a substitute of grazing and other traditional activities aiming to maintain the open character of wooded landscapes (Öllerer 2014; Moga et al. 2016).

The 'oakscape': a synthesis of the landscape features (states) fostering oak regeneration

\section{High deciduous forest: not an obvious oak habitat}

There is a conspicuous discrepancy between the character of high forest habitat, where little or no natural oak regeneration is observed, and the character of habitats successfully colonized by oaks. Conversely, most of the studies analysed involved the assessment of oak regeneration in woodlands $(74 \%$, Table 1). This may be a consequence of the economic interest for production of valuable oak timber in managed forests. However, the assumption that oaks on such sites belong to the 'potential natural vegetation' of deciduous zonal 'climax' forests, commonly named oak-beech forests (e.g. Petritan et al. 2013; Vanhellemont et al. 2014) or oak-(lime)-hornbeam forests (European Commission 2013, habitats 9160, 9170) is not consistent with the regeneration strategy of oaks. This leads to the present contradiction between the expectations regarding oak regeneration versus its reality in European zonal forests. In deciduous and mixed forests, the under-canopy level of photosynthetically active radiation (PAR) rarely reaches 15\% (von Lüpke 1998), the minimum required for sessile oak saplings growth and recruitment. In the gap dynamics, a dominating mode of natural renewal of deciduous forest temperate ecosystems, the immediate infilling of gaps by the advance regeneration of shade-tolerant species does not allow oak regeneration (Veblen 1992; Fig. 1). Because nearly all European mesic sites of deciduous and mixed forest are unable to produce and sustain advance regeneration of oaks, they could be referred to as 'recalcitrant (oak) accumulators' (Johnson et al. 2009).

Except for relatively few, dealing with post-disturbance or post-abandonment succession, most of the oak regeneration studies follow a static, deterministic approach to vegetation, expecting present stands to be replaced by their descendants. The common way of anticipating whether such scenario will be achieved is by analysing the trees frequency distribution in age (or its proxy-DBH) classes. Whilst a 'reverse-J' type of distribution is usually considered as reflecting a wellbalanced, self-replacing stand, 'bell-shaped' distributions are associated with retreating populations (e.g., Morrissey et al. 2012). Assuming that oak is a late successional species, this might imply its overarching decline. Such conclusion has recently been driven from the results of the eighty-year-long study of stands diameter structure on permanent plots in the strict nature reserve of the Białowieża National Park, revealing the oak's progressing deviation from its theoretical 'demographic equilibrium curve,' corresponding with the 'reverse-J' distribution (Brzeziecki 
et al. 2016). By analogy hardwood forestry aims to sustain the high share of oak in a tree canopy by means of silvicultural techniques securing the development of the oak successful regrowth (e.g., Shaw 1968b; Annighöfer et al. 2015; Collet et al. 2017).

There is however increasing evidence that declining oak populations in forest areas are either remnants of relatively rare and irregular 'catastrophic' disturbances (Veblen 1992) or the result of historic woodmanship (sensu Rackham 2006). Involving multiple forms of woodland use, such as coppicing with standards, hay and leaf forage making, litter raking, producing charcoal and potash, bee and game keeping. Such woodmanship entailed various anthropogenic activities that favoured opportunistic oak over the more shade-tolerant tree species (e.g., Vera 2000; Bobiec 2012; Samojlik et al. 2016). This should substantially change the perception of oaks from forest stress-tolerant competitors to 'opportunistic colonisers' in mesic deciduous and mixed forest habitats. A substantial share of oak in the canopy of contemporary broad-leaf or mixed forests, unless the result of specific silvicultural treatment, should be considered successional, following an irregular, largescale disturbance, whereas the lack of oak regeneration becomes the most frequent situation (Table 3). The oak's regeneration strategy is based on the avoidance of the typical aspects of closed forest ecosystems, including the joint effect of light deficit and browsing pressure, competition of other woody species and intensive acorn predation (Table 2).

There are wooded habitats where oaks under temperate climate sustain their dominating position in extrazonal vegetation types due to their stress tolerating advantage over other species less tolerant to edaphic poverty and/or drought. These are exemplified by acidophilous oak woods on silicate rocks, xeric oak forests on limestone, Euro-Siberian steppic woods, Pannonian-Balkanic oak forests and old oakwoods of the British Isles (habitats 9190, 91I0, 91M0, 91A0European Commission 2013). The harsh site-specific natural abiotic factors reduce the inter-species competition and prevent the development of dense, overshading scrub and stand canopies, favouring the regeneration of well-adapted species, including oaks. According to Johnson et al. (2009), xeric sites, securing competitive advantage of oaks over shadetolerant species, foster 'intrinsic oak accumulator' ecosystems, self-sustaining without support of exogenic disturbances (Table 3).

Another type of extra-zonal communities are lowland riparian communities where water logging and dynamic alluvial processes create favourable conditions for the development of willow (mainly Salix alba) and poplar (Populus nigra, P. alba) groves or Prunetalia scrub vegetation, suitable for pedunculate oak recruitment (Bakker et al. 2004; Table 3).

\section{Oaks—faithful companions of man}

These features of the oak regeneration niche could be best characterized as those of a stress-tolerant (i.e., water and nutrients shortage) 'opportunistic long-lived coloniser'. With man and his economy having become the main driving force of the European landscapes' development, creating habitats conducive to its regeneration, oak should be considered a veritable synanthropic opportunist.

Even in vast tracks of woodlands, as it was shown above, historic anthropogenic disturbances are often the most convincing explanation of oak stands establishment in the lack of artificial regeneration. In particular, woods bordering on agricultural land have usually been playing the role of 'commons' exposed to various types of human pressures (Rackham 2006; Samojlik et al. 2016). Such encroachment of agriculture into forests is responsible for development and sustenance of wide ecotone zones fostering oak regeneration and recruitment (Table 3 ).

In the reviewed collection, only a few studies deal with non-forest habitats-important components of the 'oakscape' - a landscape fostering oak regeneration, recruitment and long-term presence. Such habitats are commonly related to traditional rural economy based on multiple land use and subsistence farming, creating a diverse, fine-grain combination of various habitats, including those that are not subject to regular agronomic activities, e.g., uncultivated field margins and hedges, gradual transitions of forest margins, stone piles, roadsides, mire and oxbow edges, fallows. Such places would be naturally colonized by shrubs or trees, especially by species being seeded or planted by birds, or brought by wind (Table 3). Oaks are the most prominent representatives of the first group due to the Jay's highly specialized hoarding strategy (Kollmann and Schill 1996; Bobiec et al. 2011b). Uncultivated field margins, railway- or roadsides foster the 
Table 3 Major 'oakscape' habitat types favouring oak Quercus robur and Q. petraea spontaneous regeneration

\begin{tabular}{ll}
\hline Oakscape habitats & Oak favouring factors and processes \\
\hline $\begin{array}{l}\text { Natural gaps in rich } \\
\text { deciduous forests }\end{array}$ & $\begin{array}{c}\text { Missing or poor shrub layer and advance } \\
\text { regeneration of oak competitors; dense } \\
\text { graminoid sod; coarse woody debris provide } \\
\text { conducive structure for Jay hoarding }\end{array}$ \\
$\begin{array}{c}\text { Fallowed clear-cuts, failed } \\
\text { tree planting, anticipated by } \\
\text { the shrub layer removal }\end{array}$ & $\begin{array}{l}\text { Calamagrostis sp., limiting spontaneous } \\
\text { regeneration of oak competitors, cutting } \\
\text { residues, pioneering trees and shrubs provide } \\
\text { conducive structures for Jay hoarding }\end{array}$ \\
Degraded deciduous forests & $\begin{array}{c}\text { Selective/plunder cutting, slash burning, litter } \\
\text { removal (e.g., as the insulating material for } \\
\text { cottages and stables), development of } \\
\text { graminoid sod disfavour regeneration of oak } \\
\text { competitors; occasional ground fires can } \\
\text { increase the oaks competitive advantage over } \\
\text { other trees }\end{array}$
\end{tabular}

Forest edge zone

Mesic (mezo-) oligotrophic mixed or coniferous forests

Pine forests on sandy dunes with low ground water table

Dry slopes on calcareous bedrock

Bog pine forests

Flood-plain ecosystems

Wood-pastures

Unused or extensively used grasslands

Abandoned or extensively used meadows

Fallowed cropland

Woody field margins and hedgerows

Abandoned fruit orchards

Power line zones

Roadsides

Urban wasteland

Abandonment of agricultural activity (pasturing, mowing, ploughing), followed by wood succession, in which pioneering species and oak play the most important role; occasional grass burning can increase the oaks' competitive advantage over other trees

Missing or limited input of shade-tolerant species seeds makes oaks the major successional broadleaf species

Relatively high ecological diversity (variety of oak-acceptable microsites) and good light conditions make oak persist either as a major undergrowth or as a canopy species

Edaphic richness and high humidity level increase the oaks shade-tolerance provided by thorny shrubs or intentional pasture management favouring such species around selected saplings secure oak recruitment even under intensive grazing pressure

Crucial role of optimal light conditions and developing successional woodlots-providing conducive structures for Jay hoarding

Crucial role of existing topological structures attractive to Jays and optimal light conditions
Status in contemporary European landscapes

Extremely rare in managed forests because of the universal forestry rule of mandatory 'restocking'. The standard procedure is artificial regeneration of an opening if there is no 'promising' natural regeneration during the first 3-5 years of the gap existence.

Occasionally in large forest preserves (e.g., the Białowieża NP_-Pages and Michalet 2003; Bobiec 2007)

Locally in private or community forests, where historic, multiple use has been and is still being practiced. However, state-owned forests as well as large private or corporate holdings follow strict silvicultural regulations forbidding historic forms of forest use (e.g., litter raking or burning, cow/sheep grazing) indirect historical evidence, Bobiec 2012)

Either natural fencing (associational resistance)
Relatively common, however, unless formally protected, reclaimed mowing or ploughing can annihilate the effect of tree regeneration (e.g. Herlin and Fry 2000; Bobiec et al. 2011b)

Common in pine forests of Central Europe (e.g., Mosandl and Kleinert 1998; Kint 2005)

Commonly observed in these rare, marginal habitats (e.g., Muller 1992; Roleček 2005)

Reported from conservation areas; otherwise managed according to silvicultural regulations (e.g., Dreyer et al. 1991; Bakker et al. 2004)

In most parts of Europe a disappeared form of land use. Transylvanian wood-pastures are probably the best functioning examples (Hartel et al. 2013; Öllerer 2014)

Relatively common, however, unless formally protected, intensification of agriculture, land development or other uses can destroy the effects of spontaneous regeneration (e.g., Minotta and Degioanni 2011; Bobiec et al. 2011a, b; Kowarik et al. 2013) 
emergence and growth of mainly solitary oaks (Reif and Gärtner 2007), while permanently abandoned lots (whether crop-fields, pastures, meadows or gardens and orchards) become colonized by numerous trees, often recruited from several subsequent cohorts, which develop blocks of wooded areas, groves. Unless subject to anthropogenic pressures such as cutting or coppicing, litter raking, burning, or pasturing, oakdominated groves will gradually transform in closed forest patches with dense undergrowth, eliminating light-demanding vegetation and further oak regeneration.

Even if browsing is excluded or minimized, and there are no competing tree species, oaks are unable to regenerate directly under their own canopies (Palmer et al. 2004; Strandberg et al. 2005; Perrin et al. 2006) unless kept very open. In many parts of Europe, such groves are commonly ascribed a forest status, which implies obligatory forestry rules, that are inadequate to sustain the open character of silvopastoral oak groves (e.g., Plieninger et al. 2015). The recent shift from the rural economy based on the multiple use of variegated landscapes to intensive monocropping, including the sharp separation between open land and forests, leads to disappearance of such 'oak-friendly' habitats. The exception are oak wood-pastures, still playing an important role in local economies in South-Carpathian region (Hartel et al. 2013; Öllerer 2014). These areas of outstanding ecological value consist of grasslands with shrubs, scattered solitary trees, distinct clusters of trees with wide though not interacting canopies, and of groves, where trees interact and compete with each other (Hartel and Plieninger 2014; Table 3).

\section{Pine plantations as successful nurseries of natural oak regeneration}

Another important location for oak regeneration is under the canopy of artificial pine stands, probably the most wide-spread, quantitatively efficient contribution to the contemporary Europe's 'oakscape'. Although we have no adequate reference of an old oak stand developed from a pine plantation undergrowth, we suggest that their close historic analogies are certain oak old-growth stands developed in the Białowieża Forest in reaction to no-fire policy imposed in early 1800s on pine dominated communities (Bobiec 2012; Table 3).
Evading established vegetation categories

The cited material indicates that regeneration of oak in contemporary forests is a result of peculiar circumstances, usually involving anthropogenic disturbances. Its present analogy may be spontaneous emergence of oak groves, commonly observed on fallowed, abandoned land. Montoya et al. (2010) explored ca. half million square kilometres of Iberian Peninsula to check how selected tree species respond to habitat fragmentation with respect to the extinction threshold hypothesis. The study revealed null effects of forest fragmentation on occurrence probability of pedunculate oak, while beech has firmly met the prediction of the extinction threshold. The authors explained the $Q$. robur independence from forest cover and its immunity to forest fragmentation with zoochoric far-distance dispersal: "unlike wind, animals actively deliver seeds toward suitable (...) habitat (directed dispersal) and may increase average dispersal distances" (Montoya et al. 2010 and references therein).

We therefore suggest that European temperate landscapes might have developed as analogy to the model of the delicate and unstable balance between forest and savannah biomes proposed by Staver et al. (2011). Whether it was fire (anthropogenic or natural) or another landscape-opening factor is probably an issue of secondary importance. Most importantly, forest and savannah are two complementary types of habitats, offering very different environmental conditions, and therefore favouring different sets of species. As in Africa, where modern anthropogenic modification of the natural wild fires regime results in unprecedented spread of forest, abandonment of traditional use of European and North American savannah woods triggers their transformation to high, dense forests-habitats unsuitable both for light demanding species and for pastoral use (e.g., Strandberg et al. 2005; Moga et al. 2009; Hanberry et al. 2014).

Oaks, as many bird-dispersed species, such as shrubs and trees representing Rosaceae family or Cornus spp., abundantly regenerate in fringe-andmantle interface vegetation between forest and agricultural habitats. However, such structural complexity and 'fuzziness' is very problematic when it comes to categorization, and this is why it has often dropped off the radar in the landscape mosaic approach. We 
suspect that the widely accepted paradigm of vegetation distinct categories, entailing the pursuit of 'well representative' research plots, is a major cause of concentrating oak regeneration studies in more-or-less 'typical' forest habitats. In such habitats, however, lack of oak regeneration does not have to be considered a 'failure'. Considering the overall characteristics of species ecology, it can be just the expected, normal state.

As advised by Cushman et al. (2005), the patchmosaic model widely used in ecological studies may result in serious errors failing to reflect the true environmental heterogeneity responsible for studied organisms or processes. Acknowledging the usefulness of the traditional mosaic approach in cases of sharp environmental discontinuities, the authors suggested the necessary shift to 'the gradient paradigm', as more flexible and consistent with the true character of pattern-process relationships. Our review has revealed that oak regeneration belongs to phenomena that require the postulated change.

\section{Conclusions and implications}

The performed meta-analysis of the reviewed set of articles reflects stronger mutual affinities of most of the aspects of oak regeneration (in particular acorn dispersal, spatial pattern, growth/recruitment facilitation) as studied in a complex habitat of variegated landscapes, compared to relations between distinct factors in high forests habitats. Substantially more studies on oak seedlings/saplings growth and survival were carried out in high forest habitats than in nonforest habitats of variegated landscapes. The emerging picture supports our hypothesis that the alleged oak's 'regeneration failure' is a methodological artefact. Although most of contemporary mature and old oaks occur in high forest habitats, their spontaneous regeneration should be sought for elsewhere.

The performed review revealed a great environmental potential of the oaks regeneration niche, showing that the actual habitats fostering oak regeneration in temperate Europe are dynamic variegated landscapes. Therefore, the 'oakscape' is not a given type of habitat but rather an intricate complex of various habitats, with a conspicuous presence of oaks - both establishing stands/groves and spreading as solitaires, and providing conducive conditions to spontaneous oak regeneration and growth. Historic ways of management-Neolithic vegetation burning by hunter-gatherers, slash-and-burn economy of early farmers, silvopastoralism, subsistence family farming — created a plethora of habitats steadily colonized by oaks. Modern-age economic revolutions that aimed to intensify agricultural and timber production have led to dramatic changes in landscapes, involving a substantial loss of typical 'oakscape' components.

Four detailed conclusions can be drawn:

1. The habitually accepted assumption that $Q$. robur and $Q$. petraea are late-successional 'forest-making' trees is based on the performance of adult trees, rather than on the whole life history. Most of the identified adaptations characterising the oak regeneration niche enable oaks efficiently colonising open or semi-open habitats, but not forests, except on extreme sites. This suggests that the contemporary mature or old-growth oak stands, unless planted, are either legacies of abandoned ancient silvopastoral woods 'swallowed' by developing forest communities, or, as in Białowieża, they emerged as a result of untypical disturbances, mostly of anthropogenic origin.

2. Considering oaks as belonging to forest communities results in a conspicuous 'forest bias' in the choice of studied habitats. Only a small part of research dealing with oak regeneration has been performed in non-forest, partly wooded communities, which are best corresponding with its regeneration niche. Besides, studies evaluating oaks regeneration success (seedlings/saplings survival and growth) have usually been carried out in the context of close forest habitats.

3. The deficit of younger spontaneously regenerated oak stands in contemporary European landscapes is caused by changes in landscape management, not by intrinsic species regeneration problems. However, many important pattern-process relationships, including oak establishment, may fall out of the research focus because of the common acceptance of the simplistic landscape mosaic model, based on homogenous categories and clear-cut lines separating patches. Adaptation of the gradient approach in landscape studies would be beneficial to all species and processes, associated with 'untypical' (i.e., uncovered by recognized categories) circumstances. This particularly applies to oak regeneration. 
4. We suggest that the major cause of oaks disappearance from European landscapes is the change of the disturbance pattern at the landscape scale. The historic, long-lasting pattern of highly diversified disturbances, representing a wide spectrum of intensities and frequencies spread throughout a fine-grained texture of traditional landscapes, sustained plethora of habitats opportune for oaks establishment. The modern way of land use is based on a much simplified pattern consisting of vast monocrop fields subjected to intensive and frequent disturbances and blocks of timber woods with the disturbance dynamics unsuitable for oak spontaneous regeneration. Therefore, the most efficient way of restoring and sustaining European 'oakscapes' would be mimicking patterns of disturbance distribution, frequency and intensity throughout landscapes. This would be achievable through promotion of traditional farming (including silvopastoralism) complemented with stateof-the art scientific and technological assets.

Acknowledgements Financial support was received through the project Oak woods in rural landscapes of the Carpathian region: origin, dynamics and conservation values, financed by the National Science Centre, Poland, following the decision DEC-2013/11/B/NZ9/00793 (A.B. and K.Ö.) and through the Project No. OTKA K 119478 and RO1567-IBB03/2017 (K.Ö.). We are thankful to the reviewers for their suggestive comments. A.B. is particularly indebted to Markus Feijn for sharing his inspirational thoughts during their oak hunts in Białowieża.

Open Access This article is distributed under the terms of the Creative Commons Attribution 4.0 International License (http:// creativecommons.org/licenses/by/4.0/), which permits unrestricted use, distribution, and reproduction in any medium, provided you give appropriate credit to the original author(s) and the source, provide a link to the Creative Commons license, and indicate if changes were made.

\section{References}

Adámek M, Hadincová V, Wild J (2016) Long-term effect of wildfires on temperate Pinus sylvestris forests: vegetation dynamics and ecosystem resilience. For Ecol Manage 380:285-295

Annighöfer P, Beckschäfer P, Vor T, Ammer C (2015) Regeneration patterns of European oak species (Quercus petraea (Matt.) Liebl., Quercus robur L.) in dependence of environment and neighbourhood. PLoS ONE. https://doi.org/ 10.1371/journal.pone.0134935
Bakker ES, Olff H, Vandenberghe C, De Maeyer K, Smit R, Gleichman JM, Vera FWM (2004) Ecological anachronisms in the recruitment of temperate light-demanding tree species in wooded pastures. J Appl Ecol 41:571-582

Bideau E, Maublanc M-L, Picot D, Hamard J-P, Ballon P, Gerard J-F (2016) Short-term browsing by roe deer has little effect on survival and growth of sessile oak seedlings. Scand J For Res 31:40-45

Bobiec A (2007) The influence of gaps on tree regeneration: a case study of the mixed lime-hornbeam (Tilio-Carpinetum Tracz. 1962) communities in the Białowieża primeval forest. Pol J Ecol 55:441-455

Bobiec A (2012) Białowieża Primeval Forest as a remnant of culturally modified ancient forest. Eur $\mathrm{J}$ For Res 131:1269-1285

Bobiec A, Jaszcz E, Wojtunik K (2011a) Oak (Quercus robur L.) regeneration as a response to natural dynamics of stands in European hemiboreal zone. Eur J For Res 130:785-797

Bobiec A, Kuiper DPJ, Niklasson M, Romankiewicz A, Solecka K (2011b) Oak (Quercus robur L.) regeneration in early successional woodlands grazed by wild ungulates in the absence of livestock. For Ecol Manage 262:780-790

Bossema I (1979) Jays and Oaks: an eco-ethological study of a symbiosis. Behaviour 70:1-17

Bruun HH, Fritzbøger B (2002) The past impact of livestock husbandry on dispersal of plant seeds in the landscape of Denmark. Ambio 31:425-431

Brzeziecki B, Pommerening A, Miścicki S, Drozdowski S, Żybura H (2016) A common lack of demographic equilibrium among tree species in Białowieża National Park (NE Poland): evidence from long-term plots. J Veg Sci 27:460-469

Collet C, Manso R, Barbeito I (2017) Coexistence, association and competitive ability of Quercus petraea and Quercus robur seedlings in naturally regenerated mixed stands. For Ecol Manage 390:36-46

Crawley MJ, Long CR (1995) Alternate bearing, predator satiation and seedling recruitment in Quercus robur L. J Ecol 83:683-696

Cushman SA, Gutzweiler K, Evans JS, McGarigal K (2005) The gradient paradigm: a conceptual and analytical framework for landscape ecology. In: Moss MR, Wiens JA (eds) Issues and perspectives in landscape ecology. Cambridge University Press, Cambridge, pp 112-119

den Ouden J, Jansen PA, Smit R (2005) Jays, mice and oaks: predation and dispersal of Quercus robur and Q. petraea in north-western Europe. In: Forget PM, Lambert JE, Hulme PE, Vander Wall SB (eds) Seed fate: predation, dispersal and seedling establishment. CABI publishing, Wallingford, pp 223-240

Dreyer E, Colin-Belgrand M, Biron P (1991) Photosynthesis and shoot water status of seedlings from different oak species submitted to waterlogging. Ann For Sci 48:205-214

European Commission (2013) Interpretation manual of european union habitats. DG Environment, Brussels, Belgium. http://ec.europa.eu/environment/nature/legislation/ habitatsdirective/docs/Int_Manual_EU28.pdf

Faliński JB (1986) Vegetation dynamics in temperate lowland primeval forests. Ecological studies in Białowieża forests. Geobotany 8:1-537 
Feurdean A, Bhagwat SA, Willis KJ, Birks HJB, Lischke H, Hickler T (2013) Tree migration-rates: narrowing the gap between inferred post-glacial rates and projected rates. PLoS ONE. https://doi.org/10.1371/journal.pone.0071797

Feurdean A, Veski S, Florescu G, Vannière B, Pfeiffer M, O'Haraae RB, Stivrins N, Amon L, Heinsalu A, Vassiljev J, Hickler T (2017) Broadleaf deciduous forest counterbalanced the direct effect of climate on Holocene fire regime in hemiboreal/boreal region (NE Europe). Quat Sci Rev 169:378-390

Frelich LE, Reich PB (2002) Dynamics of old-growth oak forests in the Eastern United States. In: McShea WJ, Healy WM (eds) Oak forest ecosystems ecology and management for wildlife. The Johns Hopkins University Press, Baltimore, pp 113-126

Garbarino M, Bergmeier E (2014) Plant and vegetation diversity of European wood-pastures. In: Hartel T, Plieninger T (eds) European wood-pastures in transition: a social-ecological approach, Routledge. Taylor \& Francis Group, London, pp 113-131

Gómez JM (2003) Spatial patterns in long-distance dispersal of Quercus ilex acorns by jays in a heterogeneous landscape. Ecography 26:573-584

Götmark F, Berglund Å, Wiklander K (2005) Browsing damage on broadleaved trees in semi-natural temperate forest in Sweden with a focus on oak regeneration. Scand J For Res 20:223-234

Hanberry BB, Dey DC, He HS (2014) The history of widespread decrease in oak dominance exemplified in a grasslandforest landscape. Sci Total Environ 476-477:591-600

Hartel T, Dorresteijn I, Klein C, Máthé O, Moga CI, Öllerer K, Roellig M, von Wehrden H, Fischer J (2013) Wood-pastures in a traditional rural region of Eastern Europe: characteristics, management and status. Biol Conserv 166:267-275

Hartel T, Plieninger T (eds) (2014) European wood-pastures in transition: a social-ecological approach, Routledge. Taylor \& Francis Group, London

Herlin ILS, Fry GLA (2000) Dispersal of woody plants in forest edges and hedgerows in a Southern Swedish agricultural area: the role of site and landscape structure. Landscape Ecol 15:229-242

Hewitt GM (1999) Post-glacial re-colonization of European biota. Biol J Linn Soc 68:87-112

Humphrey JW, Swaine M (1997) Factors affecting the natural regeneration of Quercus in Scottish oakwoods.1. Competition from Pteridium aquilinum. J Appl Ecol 34:577-584

Jamrichová J, Hédl R, Kolářb J, Tóthf P, Bobek P, Hajnalová M, Procházka J, Kadlec J, Szabó P (2017) Human impact on open temperate woodlands during the middle Holocene in Central Europe. Rev Palaeobot Palynol 245:55-68

Jensen AM, Götmark F, Löf M (2012) Shrubs protect oak seedlings against ungulate browsing in temperate broadleaved forests of conservation interest: a field experiment. For Ecol Manage 266:187-193

Jensen AM, Löf M (2017) Effects of interspecific competition from surrounding vegetation on mortality, growth and stem development in young oaks (Quercus robur). For Ecol Manage 392:176-183

Johnson PS, Shifley SR, Rogers R (2009) The ecology and silviculture of Oaks, 2nd edn. CABI Publishing, Oxon
Jonsson U, Jung T, Rosengren U, Nihlgard B, Sonesson K (2003) Pathogenicity of Swedish isolates of Phytophthora quercina to Quercus robur in two different soils. New Phytol 158:355-364

Kint V (2005) Structural development in ageing temperate Scots pine stands. For Ecol Manage 214:237-250

Kollmann J, Schill H-P (1996) Spatial patterns of dispersal, seed predation and germination during colonization of abandoned grassland by Quercus petraea and Corylus avellana. Vegetatio 125:193-205

Kowarik I, von der Lippe M, Cierjacks A (2013) Prevalence of alien versus native species of woody plants in Berlin differs between habitats and at different scales. Preslia 85:113-132

Kuiters AT, Slim PA (2003) Tree colonisation of abandoned arable land after 27 years of horse-grazing: the role of bramble as a facilitator of oak wood regeneration. For Ecol Manage 181:239-251

Marçais B, Desprez-Loustau M-L (2014) European oak powdery mildew: impact on trees, effects of environmental factors, and potential effects of climate change. Ann For Sci 71:633-642

Minotta G, Degioanni D (2011) Naturally regenerated English oak (Quercus robur L.) stands on abandoned agricultural lands in Rilate valley (Piedmont Region, NW Italy). iForest $4: 31-37$

Moga CI, Hartel T, Öllerer K (2009) Ancient oak wood-pasture as a habitat for the endangered tree pipit Anthus trivialis. Biologia 64:1011-1015

Moga CI, Samoilă C, Öllerer K, Băncilă R, Réti K-O, Craioveanu C, Poszet S, Rákosy L, Hartel T (2016) Environmental determinants of the old oaks in wood-pastures from a changing traditional social-ecological system of Romania. Ambio 45:480-489

Montoya D, Alburquerque FS, Rueda M, Rodriguez MA (2010) Species' response patterns to habitat fragmentation: do trees support the extinction threshold hypothesis? Oikos 119:1335-1343

Morán-López T, Alonso CL, Díaz M (2015) Landscape effects on jay foraging behavior decrease acorn dispersal services in dehesas. Acta Oecol 69:52-64

Morrissey RC, King NT, Seifert JR, Jacobs DF (2012) Structural and compositional dynamics of a near-natural temperate deciduous forest in the central United States. J Torrey Bot Soc 139:379-390

Mosandl R, Kleinert A (1998) Development of oaks (Quercus petraea (Matt.) Liebl.) emerged from bird-dispersed seeds under old-growth pine (Pinus silvestris L.) stands. For Ecol Manage 6:35-44

Muller S (1992) Natural acidophilous Quercus and Pinus forests in the northern Vosges, France, from a geographical perspective. J Veg Sci 3:631-636

Muñoz A, Bonal R (2007) Rodents change acorn dispersal behaviour in response to ungulate presence. Oikos 116:1631-1638

Myczko Ł, Dylewski Ł, Zduniak P, Sparks TH, Tryjanowski P (2014) Predation and dispersal of acorns by European Jay (Garrulus glandarius) differs between a native (Pedunculate Oak Quercus robur) and an introduced oak species (Northern Red Oak Quercus rubra) in Europe. For Ecol Manage 331:35-39 
Öllerer K (2014) The ground vegetation management of wood pastures in Romania-insights in the past for conservation management in the future. Appl Ecol Environ Res 12:549-562

Olrik DC, Hauser TP, Kjaer ED (2012) Natural colonisation of an open area by Quercus robur L.- from where did the vectors disperse the seed? Scand J For Res 27:350-360

Onaindia M, Ametzaga-Arregi I, Sebastian MS, Mitxelena A, Rodriguez-Loinaz G, Pena L, Alday JG (2013) Can understorey native woodland plant species regenerate under exotic pine plantations using natural succession? For Ecol Manage 308:136-144

Pages JP, Michalet R (2003) A test of the indirect facilitation model in a temperate hardwood forest of the northern French Alps. J Ecol 91:932

Palmer SCF, Mitchell RJ, Truscott AM, Welch D (2004) Regeneration failure in Atlantic oakwoods: the roles of ungulate grazing and invertebrates. For Ecol Manage 192:251-265

Pausas JG, Marañón T, Caldeira M, Pons J (2009) Natural regeneration. In: Aronson J, Pereira JS (eds) Cork oak woodlands on the edge. Island Press, Washington, DC, pp 115-124

Perea R, San Miguel A, Gil L (2011a) Acorn dispersal by rodents: the importance of re-dispersal and distance to shelter. Basic Appl Ecol 12:432-439

Perea R, San Miguel A, Gil L (2011b) Flying vs. climbing: factors controlling arboreal seed removal in oak-beech forests. For Ecol Manage 262:1251-1257

Perea R, San Miguel A, Gil L (2011c) Leftovers in seed dispersal: ecological implications of partial seed consumption for oak regeneration. J Ecol 99:194-201

Perrin PM, Kelly DL, Mitchell FJ (2006) Long-term deer exclusion in yew-wood and oakwood habitats in southwest Ireland: natural regeneration and stand dynamics. For Ecol Manage 236:356-637

Peterken GF (1996) Natural woodland: ecology and conservation in northern temperate regions. Cambridge University Press, Cambridge

Petritan AM, Nuske RS, Petritan IC, Tudose NC (2013) Gap disturbance patterns in an old-growth sessile oak (Quercus petraea L.)-European beech (Fagus sylvatica L.) forest remnant in the Carpathian Mountains, Romania. For Ecol Manage 308:67-75

Plieninger T, Hartel T, Marin-Lopez B, Beaufoy G, Kirby K, Montero MJ, Moreno G, Oteros-Rozas E, Van Uytvanck J (2015) Wood-pastures of Europe: geographic coverage, social-ecological values, conservation management, and policy. Biol Conserv 190:70-79

Proença V, Pereira HM, Vicente L (2010) Resistance to wildfire and early regeneration in natural broadleaved forest and pine plantation. Acta Oecol 36:626-633

Rackham O (2006) Woodlands. Collins new naturalist. Harper Collins, London

Reif A, Gärtner S (2007) Natural regeneration of the deciduous oak species Pedunculate Oak (Quercus robur L.) and Sessile Oak (Quercrus petraea Liebl.) — a literature review with focus on wood pasture. Waldoekologie online 5:79-116 [in German with English abstract]

Roleček J (2005) Vegetation types of dry-mesic oak forests in Slovakia. Preslia 77:241-261
Samojlik T, Fedotova A, Kuijper DPJ (2016) Transition from traditional to modern forest management shaped the spatial extent of cattle pasturing in Białowieża Primeval Forest in the nineteenth and twentieth centuries. Ambio 45:904-918

Shaw MW (1968a) Factors effecting the natural regeneration of sessile oak (Quercus petraea) in North-Wales: I. A preliminary study of acorn production, viability and losses. J Ecol 56:565-583

Shaw MW (1968b) Factors effecting the natural regeneration of sessile oak (Quercus petraea) in North-Wales: II. Acorn losses and germination under field conditions. J Ecol 56:647-660

Shaw MW (1974) The reproductive characteristics of oak. In: Morris MG, Perring FH (eds) The British oak-its history and natural history. EW Classey Ltd, Faringdon, pp 162-181

Smit C, Ruifrok JL (2011) From protégé to nurse plant: establishment of thorny shrubs in grazed temperate woodlands. J Veg Sci 22:377-386

Staver AC, Archibald S, Levin SA (2011) The global extent and determinants of savanna and forest as alternative biome states. Science 334:230-232

Strandberg B, Kristiansen SM, Tybirk K (2005) Dynamic oakscrub to forest succession: effects of management on understorey vegetation, humus forms and soils. For Ecol Manage 211:318-328

van Ginkel HAL, Kuijper DPJ, Churski M, Zub K, Szafrańska P, Smit C (2013) Safe for saplings not safe for seeds: Quercus robur recruitment in relation to coarse woody debris in Białowieża Primeval Forest, Poland. For Ecol Manage 304:73-79

Van Uytvanck J, Maes D, Vandenhaute D, Hoffmann M (2008) Restoration of woodpasture on former agricultural land: the importance of safe sites and time gaps before grazing for tree seedlings. Biol Conserv 141:78-88

Vander Wall SB (2001) The evolutionary ecology of nut dispersal. Bot Rev 67:75-117

Vanhellemont M, Baeten L, Verheyen K (2014) Relating changes in understorey diversity to environmental drivers in an ancient forest in northern Belgium. Plant Ecol Evol $147: 22-32$

Veblen TT (1992) Regeneration dynamics. In: Glenn-Lewin DC, Peet RK, Veblen TT (eds) Plant succession: theory and prediction. Chapman and Hall, London, pp 152-187

Vera FWM (2000) Grazing ecology and forest history. CABI Publishing, Wallingford. https://doi.org/10.1079/ 9780851994420.0000

Vera FWM, Bakker ES, Olff H (2006) Large herbivores: missing partners of western European light-demanding tree and shrub species? In: Danell K, Bergström R, Duncan P, Pastor J (eds) Large herbivore ecology, ecosystem dynamics and conservation. Cambridge University Press, Cambridge, pp 203-231

von Lüpke B (1998) Silvicultural methods of oak regeneration with special respect to shade tolerant mixed species. For Ecol Manage 106:19-26

Watt AS (1919) On the causes of failure of natural regeneration in British oakwoods. J Ecol 7:173-203

Ziobro J, Koziarz M, Havrylyuk S, Korol M, Ortyl B, Wolański P, Bobiec A (2016) Spring grass burning: an alleged driver of successful oak regeneration in sub-carpathian marginal woods. a case study. Prace Geograficzne 146:67-88 